\title{
白色顔料開発を目指したチタニア被覆シリカ複合中空粒子の合成
}

\author{
藤 正督 ${ }^{1 *}$, 飯田 隆寛 ${ }^{1}$, 高井 千加 ${ }^{2}$, 冨岡 達也 ${ }^{1}$, Hadi Razavi-Khosroshahi ${ }^{1}$
}

\section{Preparation of Titania Coated Silica Hollow Particles for White Pigment}

\author{
Masayoshi Fuji ${ }^{1 *}$, Takahiro Iida ${ }^{1}$, Chika Takai ${ }^{2}$, Tatsuya Tomioka ${ }^{1}$ and Hadi Razavi-Khosroshahi
}

Received 3 April 2019; Accepted 8 July 2019

\begin{abstract}
Titania coated silica hollow particles were developed as a white pigment to prevent their sedimentation during storage. The hollow silica particles used in this study have porous structure, which is expected to have both scatter and transmit visible light to help to improve the titania's covering power. The template for such porous structure was prepared by gathering nano-sized calcium carbonate via $\mathrm{CO}_{2}$ gas bubbling method. For the titania coating, acetic acid was used to control too quick chemical reaction of titania precursor by forming chelate compound. The molar ratios of water/titania and reaction temperature were optimized. The obtained titania coated hollow silica particles exhibited higher whiteness than the commercial $\mathrm{TiO}_{2}$.
\end{abstract}

Keywords: Titania, Silica, Hollow particles, Sol-gel method, Chelate compound.

\section{1. 緒言}

中空粒子は内部空洞と固体シェルからなり，同粒子径 の中実粒子とは異なるユニークな性質を示す。その違い は内部空洞径の減少とともにより顕著に現れる。著者ら はこれまでに，ナノサイズのシリカ中空粒子をポリマー 中に充填させた複合フィルムが，空気と同等の高い断熱 性[1]や光拡散性[2]を示すことを明らかにした。適した分 散処理を施しフィルム中粒子の分散性を向上させると, 空ガラスに貼り付けても視野を妨げない高い透過性を持 つ[1]。また, 光拡散能は, 中空内部とシェルの屈折率差 が光散乱サイトとなること, 散乱光が中空粒子内部を透 過することにより得られると考えられる。

チタニア $\left(\mathrm{TiO}_{2}\right)$ は高屈折材料であり隠ぺい力が高い ことから, トナー用添加剤, 化学繊維用豊消し剂などと して用いられている。しかし，比重が大きいことから， 沈降防止技術が必要となる。液相中で行う粒子合成では, チタンアルコキシドをチタニア源として用いることが多 いが，アルコキシドの加水分解速度が速いため，酢酸や アセチルアセトンなどキレート形成能を持つ化合物を利

1 名古屋工業大学 先進セラミックス研究センター

( ⿳ 507-0033 岐阜県多治見市本町 3-101-1)

Advanced Ceramics Research Center, Nagoya Institute of Technology

(3-101-1 Honmachi, Tajimi, Gifu 507-0033, Japan)

2 岐皁大学 工学部

（广 501-1193 岐阜市柳戸町 1-1）

Faculty of Engineering, Gifu University

(1-1 Yanagido, Gifu 501-1193, Japan)

* Corresponding Author fuji@nitech.ac.jp
用して反応速度を調整する手法が用いられる[3-5]。

内部空隙率の高い中空粒子は, 中実粒子と比べて沈降 速度が遅い。また，粒子間付着力も小さいと考えられる [6]。さらに, 上述のように可視光に対する散乱能も高 い。そこで, 本研究では, 酸化チタンが持つ隠ぺい力と, 中空粒子が持つ遅沈降性, 散乱性を組み合わせた複合粒 子の合成を提案する。中空粒子は, 炭酸カルシウムをテ ンプレートとした無機テンプレート法[7]を基盤とし， $50 \mathrm{~nm}$ 程度の炭酸カルシウム粒子をサブミクロンオーダー に凝集させたテンプレートの設計[8]から検討した。炭酸 カルシウム一次粒子にシリカが被覆され，外径 $500 \mathrm{~nm}$ 程度の多孔質構造を有する中空シリカ粒子を得た。1 個 の中空粒子が多くの内部空洞とシリカシェルを持つこと から散乱サイトを多く有することが期待できる。チ夕ニ ア源としてチタン（IV）テトラブトキシド (TBOT), 錯 体形成能を持つ酢酸を用い, シリカシェル表面へのチ夕 ニア被覆条件について検討した。TBOT-酢酸錯体は，水 の存在や加温により加水分解反応を開始する。そこで, $\left[\mathrm{H}_{2} \mathrm{O}\right] / \mathrm{Ti}$ 比および反応温度がチタニア層形成に与える影 響について調べ, 最適条件で合成したチタニア／シリカ 複合中空粒子の白色度を評価した。

\section{2. 実験方法}

\section{1 炭酸カルシウムテンプレートの合成}

Fig. 1 に示す反応装置を用い, 炭酸ガスバブリング法 により炭酸カルシウムテンプレート合成を行った[8]。反 応溶媒メ夕ノール $1 \mathrm{~L}$ 中に, カルシウム源として水酸化 カルシウムを $30 \mathrm{~g}$ 投入後, $20^{\circ} \mathrm{C}$ となるう液温を調整 


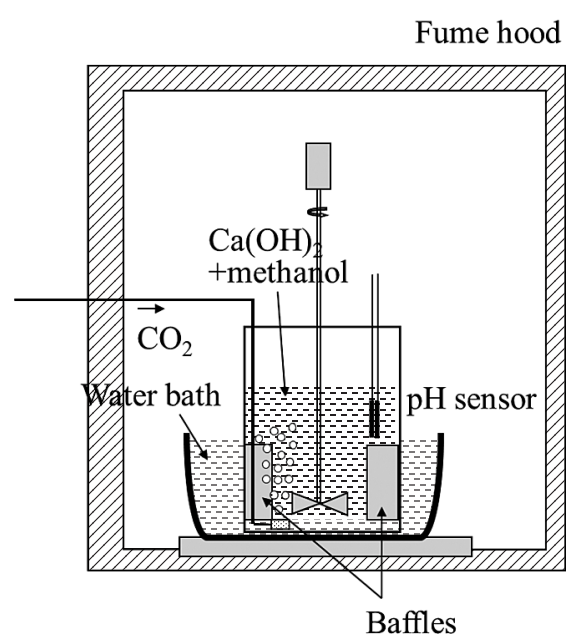

Fig. 1 Reaction apparatus to synthesize calcium carbonate templates

し，ステンレス羽根を回転数 $700 \mathrm{rpm}$ で回転させて摚汼 した。その後, 炭酸ガスを $0.6 \mathrm{~L} / \mathrm{min}$ の条件で反応溶液中 にバブリングした。溶液の $\mathrm{pH}$ が 7.6 に到達したところで バブリングを止めた。白濁した溶液は静置後約 3 時間程 度でゲル化が始まる。約 5 時間程度で完全にゲル化し, さらに 10 時間放置するとゾル化してほぼ均一な $500 \mathrm{~nm}$ の炭酸カルシウムの懸濁液へと変化する。この懸濁液を 万過し, $120^{\circ} \mathrm{C}$ で 5 時間乾燥させ, 粉体を得た。

\section{2 シリカ中空粒子の合成}

前項で合成した炭酸カルシウムをエタノール／蒸留水 混合溶媒に加え, 超音波分散処理を 10 分間施した。アン モニア水，シリカ源であるテトラエトキシシラン（TEOS） を加え室温で 2 時間攪拌後, 固液分離, 洗浄した。 $3 \mathrm{~mol} / \mathrm{L}$ 塩酸を加えコア除去することでシリカ中空粒子を得た。

\section{3 チタニア被覆シリカ中空粒子の合成}

前項で合成したシリカ中空粒子 $0.50 \mathrm{~g}$ を1-ブタノール $77.0 \mathrm{~g}$ に加え, 10 分間超音波分散処理後, 室温で 30 分擋 拌した TBOT $(30.0 \mathrm{~g})$ /酢酸（8.10 g) /1-ブタノール
$(39.0 \mathrm{~g})$ 溶液を加えた。30 分室温で攪拌後, 蒸留水 $1.19 \mathrm{~g}$ を加えた。さらに 30 分攪拌後に蒸留水 $2.38 \mathrm{~g}$ を加え 30 分攪拌した。その後, 固液分離, 洗浄を 2 回行った。 $130^{\circ} \mathrm{C}$ で 1 時間乾燥後, $550^{\circ} \mathrm{C}$ で 3 時間大気雲囲気下に て熱処理し,シリカ/チタニア複合中空粒子を得た。 $\left[\mathrm{CH}_{3} \mathrm{COOH}\right] /[\mathrm{Ti}]=1.5,[\mathrm{Ti}] /[\mathrm{Si}]=10$ の 2 つのモル比は固 定した。粒子構造は走査型電子顕微鏡 (JSM-7600F, JEOL 社製）および透過型高分解能電子顕微鏡（JEM-2010HR, JEOL 社製）により観察し, energy dispersive X-ray spectrometry（EDS）検出器により元素分析を行った。結 晶構造は X 線回折 (XRD) を用いて評価した。窒素吸着

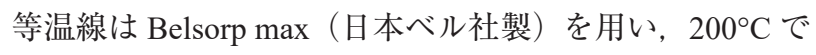
2 時間乾燥をした後測定を行い, Brunauer-Emmett-Teller （BET）法により比表面積を, Barrett, Joyner, Hallenda （BJH）法により平均細孔径を算出した。白色度 W は, JIS8148 に従い, $\mathrm{W}=0.847 \mathrm{Z}$ 用いて算出した。 Z は XYZ 表色系の Z 值であり, 紫外可視近赤外分光光度計 (UVVis-NIR, UV-3150, 島津製作所社製）の拡散反射率を用 いて算出したものである。

\section{3. 実験結果および考察}

\section{1 炭酸カルシウムテンプレートの合成と評価}

Fig. 2 (a)(b) に合成した炭酸カルシウム粒子の SEM 写 真を示す。低倍観察写真から, 楕円形状の粒子が生成し ていることがわかる。短径はおよそ $500 \mathrm{~nm}$, 長径はおよ そ $1 \mu \mathrm{m}$ である。高倍観察写真から, 楕円形状の粒子は 一次粒子径 $50 \mathrm{~nm}$ 程度の球状粒子の集合体であることが わかる。Fig. 2 (c) に, 同粒子の XRD パターンを示す。 ○で示した回折ピークはバテライト由来のものであり, ほぼバテライトとして生成していることがわかる。29付 近のピークはカルサイトである。

実験項に記したように, メタノールに水酸化カルシウ ムを溶解させ, 溶液の $\mathrm{pH}$ が 7.6 になるまで炭酸ガスをバ ブリングして生成した白濁した溶液は静置後約 3 時間程 度でゲル化が始まる。約 5 時間程度で完全にゲル化し,
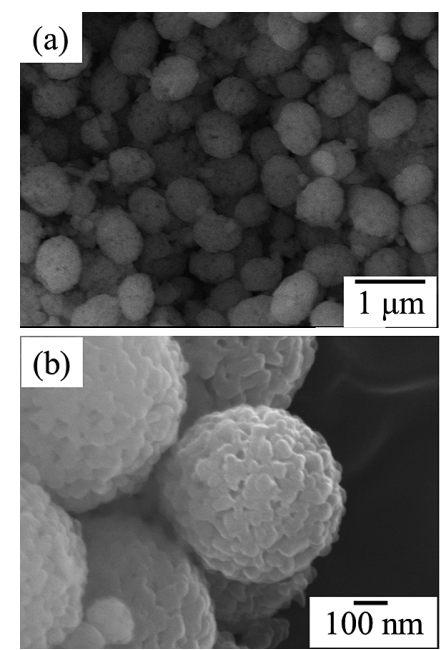

(c)

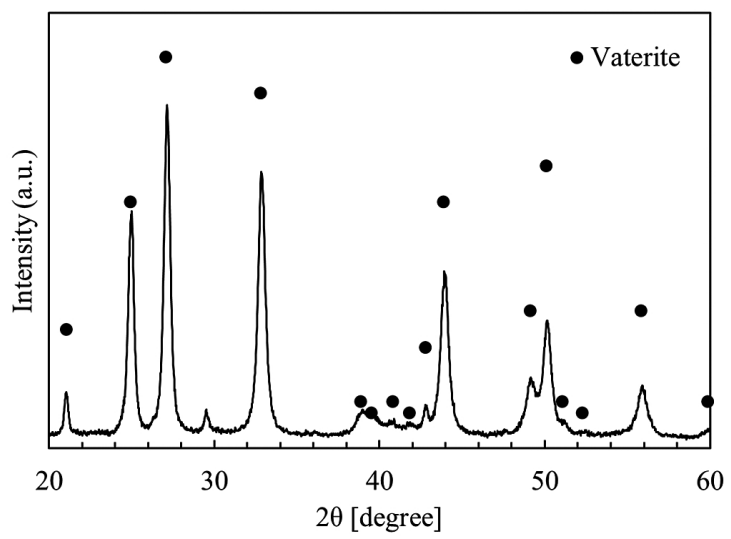

Fig. 2 (a)(b) SEM micrographs of the calcium carbonate templates with different magnifications and (c) XRD patterns 
さらに 10 時間放置するとゾル化してほぼ均一な $500 \mathrm{~nm}$ の炭酸カルシウムの懸濁液へと変化する。この $500 \mathrm{~nm}$ の炭酸カルシウムが一次粒子 $50 \mathrm{~nm}$ の微粒子が集合した 楕円形バテライト粒子である。現在のところ, 楕円形状 を形成するメカニズムは明らかではないが, ゲル崩壊時 にアモルファスの一次粒子が析出（約 30〜 $50 \mathrm{~nm}$ ） し, ゾル化の過程で凝集して楕円形状の二次粒子が生成した と考えている。

\section{2 シリカ中空粒子の合成と評価}

前節で合成した炭酸カルシウムをテンプレートとし, ゾルゲル法によりシリカコーティング (コアシェル粒子) および酸処理によりテンプレートを除去しシリカ中空粒 子を合成した。Fig. 3 (a) にコアシェル粒子の SEM 画像 を示す。Fig. 2 (b) と比較して, テンプレート表面の平滑 性が増していることがわかる。Fig. 3 (b) に塩酸処理後の TEM 画像を示す。テンプレートが除去され, 内部空洞が 確認できる。粒子内部は Fig. 2 (b) の炭酸カルシウム凝集 体構造を反映し, 多孔質構造となっている。高倍画像か ら, シリカシェル厚は約 $6 \mathrm{~nm}$ である。テンプレートを 構成する一次粒子一つ一つにシリカがコーティングされ, 塩酸処理中に壊れることなく構造を維持していることが わかる。

炭酸カルシウムテンプレート, コアシェル粒子, シリ カ中空粒子の窒素吸脱着等温線を Fig. 3 (c) に示す。縦軸 の窒素吸着量を見ると, シリカコーティング後に減少し, 酸処理後に大きく増加していることがわかる。

炭酸カルシウムの密度を $2.5 \mathrm{~g} / \mathrm{cm}^{3}$ とし, 粒子径 $500 \mathrm{~nm}$ としたときの比表面積を計算すると $4.80 \mathrm{~m}^{2} / \mathrm{g}$ となる。合 成した炭酸カルシウムは約 8 倍の比表面積を有すること になる。脱着等温線から BJH 理論により算出した平均細 孔径は $22.57 \mathrm{~nm}$ である。合成した炭酸カルシウムの一次
粒子径が約 $50 \mathrm{~nm}$ であるので, 一次粒子が凝集し楕円形 状を形成した際の一次粒子間隙が細孔として算出された と考えられる。

シリカコーティング後のコアシェル粒子の比表面積は 約半分 $\left(19.72 \mathrm{~m}^{2} / \mathrm{g}\right)$ に減少し, 平均細孔径は $17.53 \mathrm{~nm}$ となった。先述のように炭酸カルシウム一次粒子にシリ カがコーティングされていることが Fig. 3 (b) の TEM 像 より明らかである。コアシェル粒子の比表面積減少は, 粒子内部の細孔にシリカ源が入り込んだことによると考 えられる。Fig. 3 (a)のコアシェル粒子表面は Fig. 2 (b) の テンプレートと比較して表面凹凸は減少したものの粗さ は残っている。したがって理論值よりは大きな比表面積 を維持している。

塩酸処理後の中空粒子の比表面積 $\left(280.59 \mathrm{~m}^{2} / \mathrm{g}\right)$ は, コアシェル粒子 $\left(19.72 \mathrm{~m}^{2} / \mathrm{g}\right)$ と比較して 10 倍以上増加 した。窒素吸着等温線（Fig. 3 (c)）の低相対圧で見られ る立ち上がりは $2 \mathrm{~nm}$ 以下のマイクロ孔の存在を示して いる。炭酸カルシウムは酸性条件下で $\mathrm{CaCl}_{2}$ と $\mathrm{CO}_{2}$ に分 解されるが, これらはシリカシェルのマイクロ孔を通じ て排出される[7]。窒素吸着はこのマイクロ孔を通じてシ リカシェル内表面にも起こると考えられ, 比表面積の増 加はシリカシェル内表面との和によるものと示唆される。 また, 中空粒子の吸脱着等温線に見られるヒステリシス は, メソ孔の存在を示唆している。BJH 理論を用いて平 均細孔径は $17.29 \mathrm{~nm}$ と算出された。これはコアシェル粒 子の細孔径 $(17.53 \mathrm{~nm})$ と比べて大きな変化はない。炭 酸カルシウム一次粒子の間隙はシリカが詰まっていると 予測される。

\section{3 チタニア被覆シリカ中空粒子の合成と評価 3.3.1 蒸留水添加量の影響}

前項で合成したシリカ中空粒子／1-ブタノールに, 酢
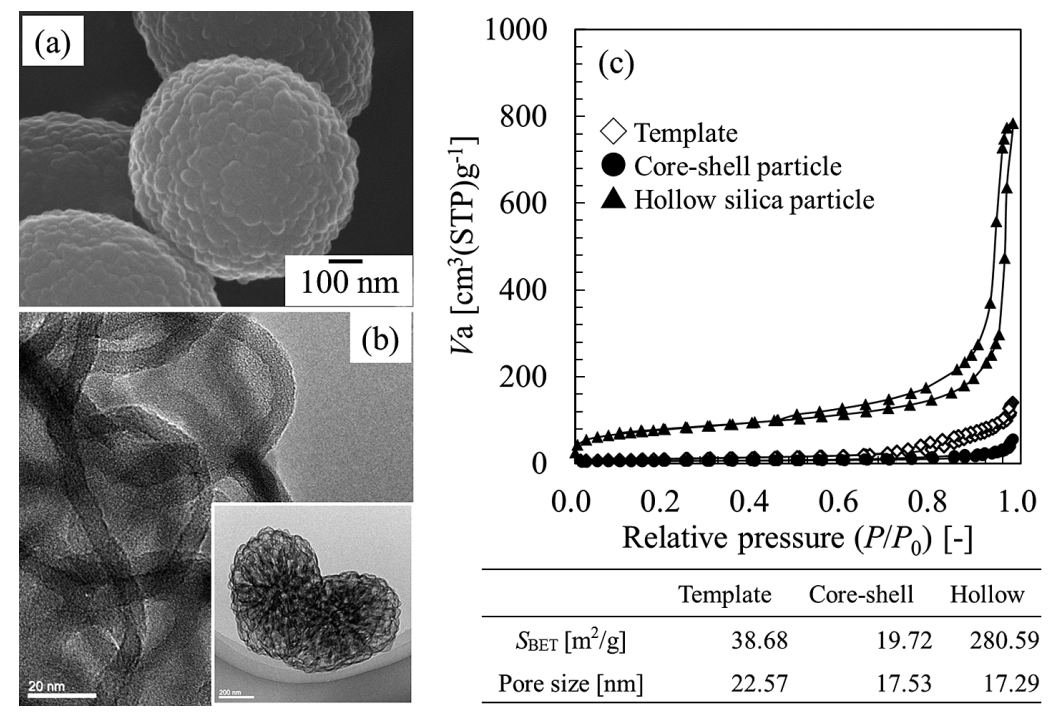

Fig. 3 (a) SEM image of the core-shell particle (before acid etching), (b) TEM images of the hollow silica particles, and (c) nitrogen gas adsorption desorption isotherms of them with the calcium carbonate template (up) and list of calculated specific surface area by BET equation $\left(S_{\mathrm{BET}}\right)$ and average pore size by BJH theory (bottom) 
Table 1 Synthetic conditions to investigate effect of adding water amount

\begin{tabular}{|c|c|c|c|c|c|c|}
\hline & $\begin{array}{l}\text { TBOT } \\
{[\mathrm{ml}]}\end{array}$ & $\begin{array}{c}\text { Acetic acid } \\
{[\mathrm{ml}]}\end{array}$ & $\begin{array}{c}\text { 1-butanol } \\
\text { For TBOT/hollow } \\
{[\mathrm{ml}]}\end{array}$ & $\begin{array}{c}\text { Hollow particle } \\
{[\mathrm{g}]}\end{array}$ & $\begin{array}{l}\text { Distilled water } 1^{\mathrm{st}} / 2^{\text {nd }} \\
{[\mathrm{ml}]}\end{array}$ & $\begin{array}{c}\text { Molar ratio of } \\
{\left[\mathrm{H}_{2} \mathrm{O}\right] /[\mathrm{Ti}]}\end{array}$ \\
\hline (a) $\mathrm{WT}_{0.7}$ & \multirow{4}{*}{15.8} & \multirow{4}{*}{4.2} & \multirow{4}{*}{$24.0 / 48.0$} & \multirow{4}{*}{0.26} & $0 / 0.62$ & 0.7 \\
\hline (b) $\mathrm{WT}_{2.2}$ & & & & & $0.62 / 1.25$ & 2.2 \\
\hline (c) $\mathrm{WT}_{4.5}$ & & & & & $1.25 / 2.5$ & 4.5 \\
\hline (d) $\mathrm{WT}_{9.0}$ & & & & & $2.5 / 5.0$ & 9.0 \\
\hline
\end{tabular}

Table 2 EDS analysis for $\mathrm{Si}$ and Ti ratios in the composite particles

\begin{tabular}{ccc}
\hline & $\mathrm{Si}$ & $\mathrm{Ti}$ \\
\cline { 2 - 3 } & \multicolumn{2}{c}{$[$ [mass\%] } \\
\hline (a) $\mathrm{WT}_{0.7}$ & 93.22 & 6.78 \\
(b) $\mathrm{WT}_{2.2}$ & 92.94 & 7.06 \\
(c) $\mathrm{WT}_{4.5}$ & 71.87 & 28.13 \\
(d) $\mathrm{WT}_{9.0}$ & 4.58 & 95.42 \\
\hline
\end{tabular}

酸とキレート形成した TBOT/1-ブタノール溶液を加えた。 この懸濁液に蒸留水を加えることで TBOT の反応を開始 させ，チタニア被覆シリカ中空粒子を合成した。

Ohno らは, キレート化した TBOT の加水分解に用い る蒸留水を二度に分けて添加することがシリカとチタニ アの複合化に重要であると報告している $[3]$ 。本研究で は, 一回目と二回目の蒸留水添加は 30 分間空けて行っ た。Table 1 に示すように一回目と二回目の蒸留水添加割 合は一定とし, 添加量総量とチタニアの比 $\left[\mathrm{H}_{2} \mathrm{O}\right] /[\mathrm{Ti}]$ がチ タニア複合化に与える影響を調査した。Ohnoらの報告を 参考に $\left[\mathrm{CH}_{3} \mathrm{COOH}\right] /[\mathrm{Ti}]=1.5,[\mathrm{Ti}] /[\mathrm{Si}]=10$ （どちらもモ ル比）を固定した。

$\left[\mathrm{H}_{2} \mathrm{O}\right] /[\mathrm{Ti}]$ 比を $0.7 ， 2.2 ， 4.5 ， 9.0$ としたサンプルをお のおの $\mathrm{WT}_{0.7}, \mathrm{WT}_{2.2}, \mathrm{WT}_{4.5}, \mathrm{WT}_{9.0}$ とした。乾燥後の $\mathrm{WT}_{0.7}, \mathrm{WT}_{2.2}, \mathrm{WT}_{4.5}$ は白色であった。 $\mathrm{WT}_{9.0}$ は蒸留水添 加後に懸濁液が流動性を失いゲル化した。乾燥後は黄色 を呈しており, 熱処理後も若干黄色を帯びていた。Table 2 に示すように EDS 分析により検出された Ti の重量\%は,
$\mathrm{WT}_{0.7}, \mathrm{WT}_{2.2}, \mathrm{WT}_{4.5}$ の順に, 6.78, 7.06, 28.13\%であり, 添加水量の増加とともにチタニアの生成が促進されてい ることがわかる。しかし， $\mathrm{WT}_{9.0}$ の SEM 観察視野には, $10 \mathrm{~nm}$ オーダーのチタニア微粒子がミクロンオーダーの 凝集体も見られた。 $\left[\mathrm{H}_{2} \mathrm{O}\right] /[\mathrm{Ti}]=9.0$ の条件は, チタニア の加水分解反応が過剩に促進され, シリカシェル外でも 進行したと考えられる。

Fig. 4 (a) に示すように, UV-vis 分光光度計を用いた吸 光度測定ではすべてのサンプルにチタニア由来の吸収が 見られた。市販チタニア粒子（ST-01, 石原産業社製）と 比較して $\mathrm{WT}_{4.5}, \mathrm{WT}_{2.2}, \mathrm{WT}_{0.7}$ の吸収波長が低波長にシフ トしていることから, $20 \mathrm{~nm}$ 以下のチタニア微粒子の生 成が示唆される。Fig. 4 (b) にこれらの XRD 結果を示す。 $\mathrm{WT}_{9.0}$ に見られるアナターセ由来の回折ピークは, 上述 の過剩に生成したチタニア粒子によるものと考えられる。 $\mathrm{WT}_{4.5}, \mathrm{WT}_{2.2}, \mathrm{WT}_{0.7}$ の蒸留水添加量の減少とともに, ア ナターセ由来のピークは減少した。

EDS 分析結果から, チタニアシェル厚を推測した。中 空粒子の内部空洞の直径が $500 \mathrm{~nm}$, シリカシェル厚が $10 \mathrm{~nm}$ と仮定し, シリカシェルにチタニアが均一にコー ティングされたとすると, $\mathrm{WT}_{0.7}, \mathrm{WT}_{2.2}, \mathrm{WT}_{4.5}$ のチタニ アシェル厚は, $0.4,0.4,2.1 \mathrm{~nm}$ と計算された。今回用 いた $[\mathrm{Ti}] /[\mathrm{Si}]=10$ の条件で, 添加した TBOT 全量がチ夕 ニアに転化しシェルを形成したと仮定すると, 約 $70 \mathrm{~nm}$ の厚みのチタニアシェルが形成されるはずである。TBOT酢酸錯体の反応性を上げる必要がある。 (a)

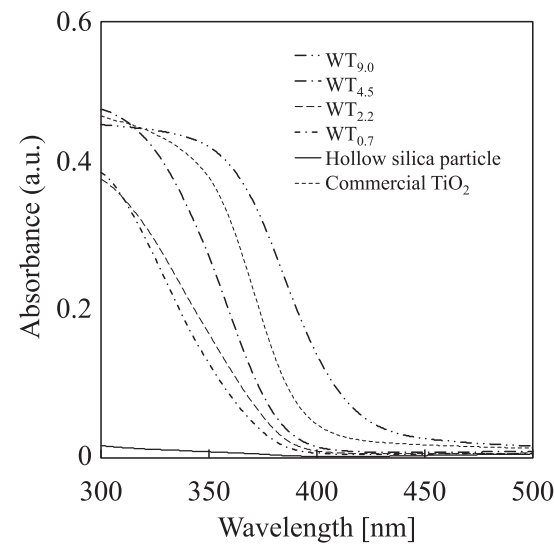

(b)

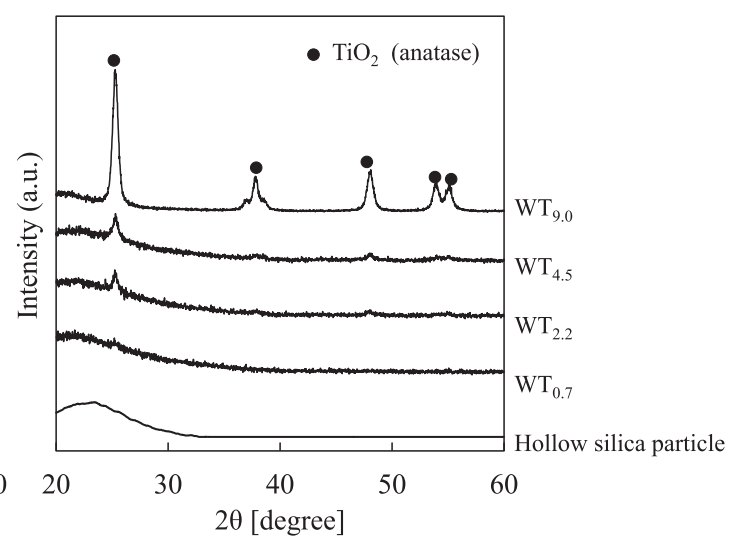

Fig. 4 (a) UV-vis spectra of $\mathrm{WT}_{0.7}, \mathrm{WT}_{2.2}, \mathrm{WT}_{4.5}, \mathrm{WT}_{9.0}$, with as-synthesized hollow silica particles and commercial $\mathrm{TiO}_{2}$ as references and (b) XRD patterns of corresponding samples 
(a)

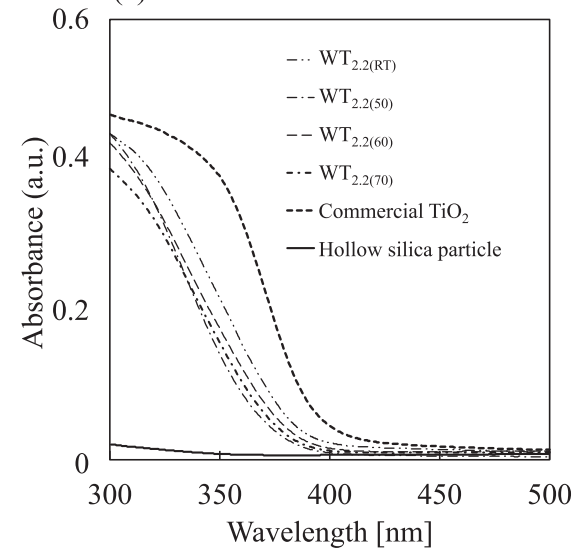

(b)

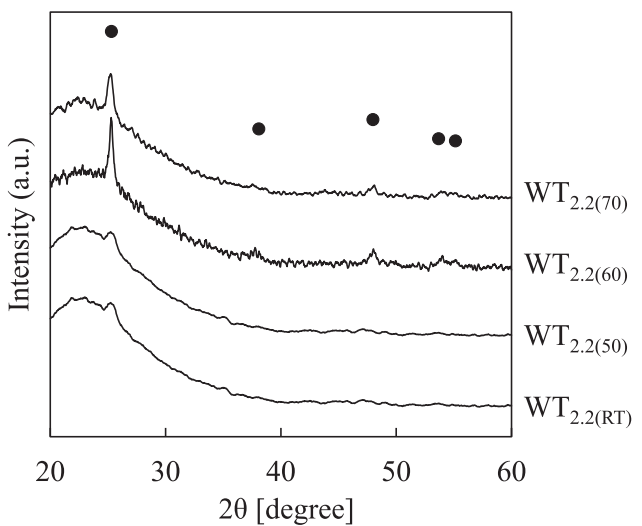

Fig. 5 (a) UV-vis spectra of $\mathrm{WT}_{2.2(\mathrm{RT})}, \mathrm{WT}_{2.2(50)}, \mathrm{WT}_{2.2(60)}, \mathrm{WT}_{2.2(70)}$ with as-synthesized hollow silica particles and commercial $\mathrm{TiO}_{2}$ as references and (b) XRD patterns of corresponding samples

\subsection{2 反応温度の影響}

Baskaran らは，シリコン基板温度を上げることで，基 板上のチタニア層を厚くすることが可能であることを報 告している[9]。具体的には, 基板温度 $22,40,70,93^{\circ} \mathrm{C}$ のとき，チタニア層厚が $10 ， 40 ， 49 ， 51 \mathrm{~nm}$ となった。 これを参考に, シリカ中空粒子へのチ夕ニア複合量の増 加を目的として，二回目の蒸留水添加時の温度変化（室 温， 50，60，70 $\mathrm{C}$ ) によるチタニア生成への影響を調査 した。そのほかの条件は, $\mathrm{WT}_{2.2}$ と同様である。おのお の名称を $\mathrm{WT}_{2.2(\mathrm{RT})}, \mathrm{WT}_{2.2(50)}, \mathrm{WT}_{2.2(60)}, \mathrm{WT}_{2.2(70)}$ とする。

Fig. 5 (a) に各粒子の可視光波長に扔ける吸光度測定結 果を示す。比較試料としてシリカ中空粒子および Fig. 4 と同様に市販チタニアナノ粒子を載せた。すべてのサン プルにおいて, $400 \mathrm{~nm}$ 付近から吸収が見られた。市販于 タニアの吸収ピークの立ち上がりと比較すると, すべて のサンプルにおいて吸収波長が低波長側にシフトしてい る。バンドギャップ（BG）エネルギーは， $3.42 \mathrm{eV}$ $\left(\mathrm{WT}_{2.2(\mathrm{RT})}\right), 3.58 \mathrm{eV}\left(\mathrm{WT}_{2.2(50)}\right), 3.52 \mathrm{eV}\left(\mathrm{WT}_{2.2(60)}\right), 3.51 \mathrm{eV}$ $\left(\mathrm{WT}_{2.2(70)}\right)$ と算出された。市販チタニアの BG エネルギー は $3.13 \mathrm{eV}$ であるから，すべてのサンプルにおいて $\mathrm{BG}$ エネルギーが増加したことになり，複合粒子に存在する チタニアが $20 \mathrm{~nm}$ 以下のサイズで形成していることが示 唆される。特に反応温度 $50^{\circ} \mathrm{C}$ で合成したサンプルの BG エネルギーシフトがもっとも大きくなった。Fig. 5 (b) に 各サンプルの XRD 測定結果を示す。 $\mathrm{WT}_{2.2(\mathrm{RT})}$ 拈よび $\mathrm{WT}_{2.2(50)}$ では $25^{\circ}$ 付近にのみ(020)面のアナターゼ型チタニ ア由来の回折ピークが観察された。 $\mathrm{WT}_{2.2(60)}, \mathrm{WT}_{2.2(70)}$ で は高角側にもアナターゼ型のピークが出現した。特に反 応温度 $60^{\circ} \mathrm{C}$ で合成したサンプルに結晶性の高いチタニ アが含まれることがわかった。

Fig. 6 に各サンプルの高倍 TEM 画像を示す。矢印で示 したように, $2 \mathrm{~nm}$ 程度の粒子状物が観察され，複合化さ れたチ夕ニア粒子であると考えられる。また，低倍観察 においても楕円形状の中空粒子構造は維持されており, チタニア複合化抢よび熱処理などのプロセスにおいても 構造の破壊が起こらないことも確認できている。
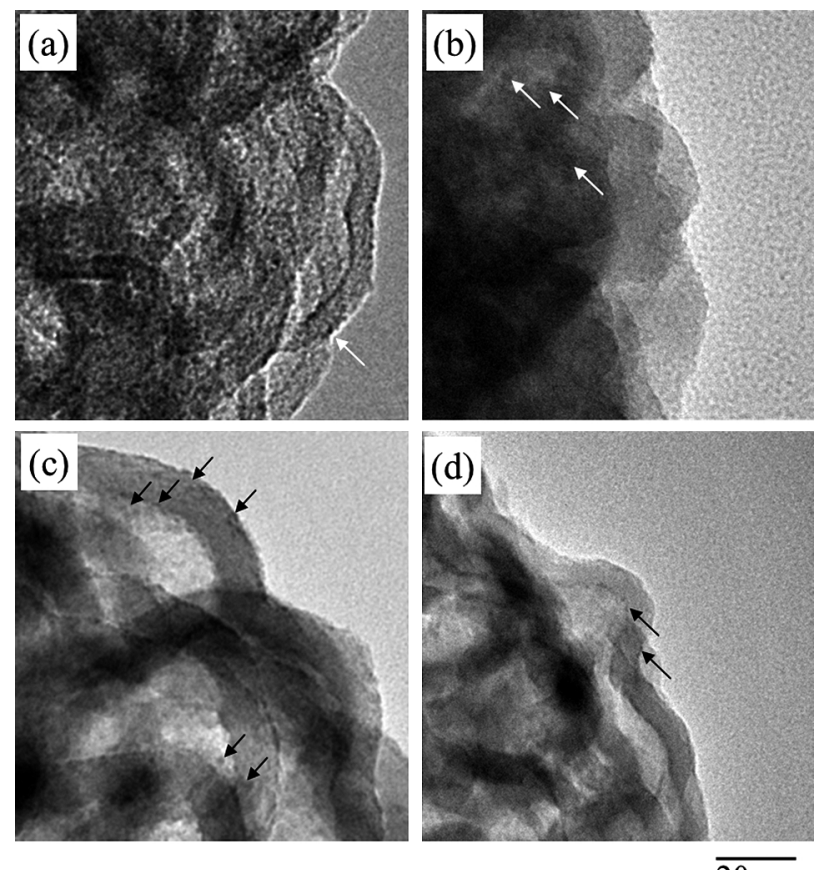

$\overline{20 \mathrm{~nm}}$

Fig. 6 Enlarged TEM images of $\mathrm{WT}_{2.2(\mathrm{RT})}, \mathrm{WT}_{2.2(50)}, \mathrm{WT}_{2.2(60)}$, $\mathrm{WT}_{2.2(70)}$

EDS 分析による Ti/Si 比から計算したチタニアシェル 厚は $2.1 \mathrm{~nm}\left(\mathrm{WT}_{2.2(\mathrm{RT})}\right), 9.3 \mathrm{~nm}\left(\mathrm{WT}_{2.2(50)}\right), 12.9 \mathrm{~nm}$ $\left(\mathrm{WT}_{2.2(60)}\right), 2.3 \mathrm{~nm}\left(\mathrm{WT}_{2.2(70)}\right)$ であった。シリカ中空粒子 の仮定は上述と同様である。溶液温度を $50,60^{\circ} \mathrm{C}$ に上 げることでシリカシェルへのチタニア複合化が促進でき

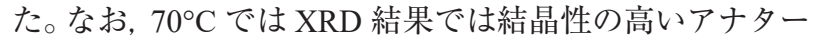
セ生成が確認できているが, 温度上昇に伴うチタニアシェ ル厚は減少していることから, チ夕ニア複合化がシリカ シェル以外にも行われていることが示唆される。 $\mathrm{WT}_{22(50)}$ の水分散液の等電点は $\mathrm{pH} 4.60$ であった。シリカ中空粒 子が $\mathrm{pH} 3.81, \mathrm{WT}_{2.2}$ が $\mathrm{pH} 3.84$, 市販チタニアが $\mathrm{pH} 5.91$ であるから、シリカシェル表面にチ夕ニアが存在してい ることが示唆され, それは溶液温度の増加により促進さ れる。各粒子の BET 比表面積および全細孔容積 $\left(P / P_{0}=\right.$ 
Table 3 BET surface area and total volume of the composite particles

\begin{tabular}{|c|c|c|c|c|c|c|}
\hline & $\mathrm{WT}_{2.2(\mathrm{RT})}$ & $\mathrm{WT}_{2.2(50)}$ & $\mathrm{WT}_{2.2(60)}$ & $\mathrm{WT}_{2.2(70)}$ & Hollow $\mathrm{SiO}_{2}$ & $\begin{array}{c}\text { Hollow } \mathrm{SiO}_{2} \\
\left(550^{\circ} \mathrm{C} \text { heated }\right)\end{array}$ \\
\hline BET surface area $\left[\mathrm{m}^{2} / \mathrm{g}\right]$ & 144 & 202 & 133 & 130 & 267 & 276 \\
\hline Total pore volume $\left[\mathrm{cm}^{3} / \mathrm{g}\right]\left(P / P_{0}=0.990\right)$ & 1.05 & 0.88 & 1.05 & 1.10 & 1.50 & 1.59 \\
\hline
\end{tabular}

(a)

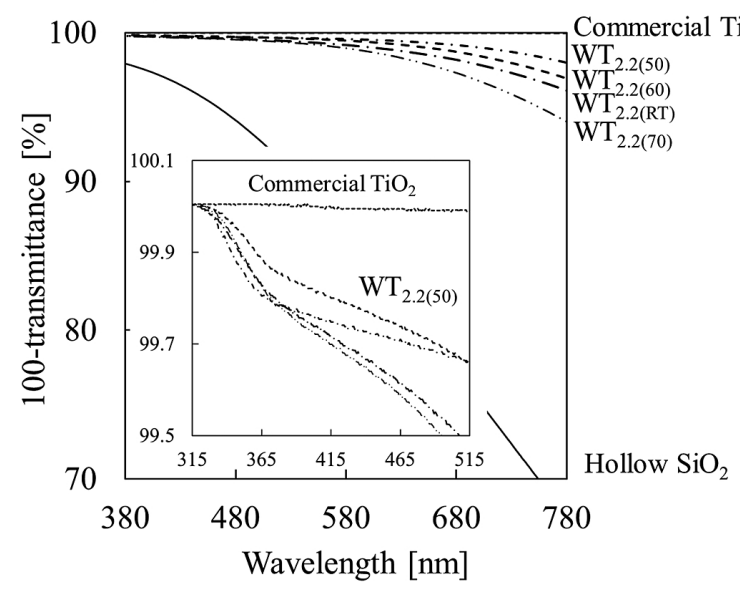

(b)

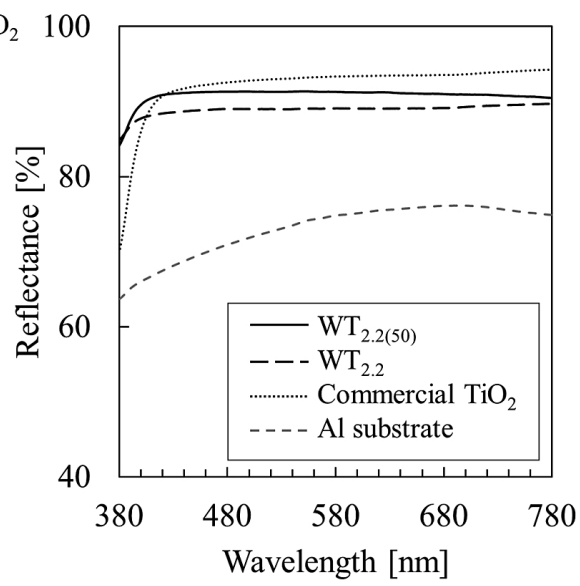

Fig. 7 (a) Shielding rate (100-transmittance) of the composite particles suspensions and (b) reflectance of the composite particles which were coated on the Al substrates

0.990）を Table 3 に示す。比較としてチタニア被覆前の シリカ中空粒子，およびチタニア被覆時の $550^{\circ} \mathrm{C}$ 熱処理 を施したシリカ中空粒子の評価結果も示す。チタニア被 覆後の複合粒子は比表面積が半減しており，これは，細 孔容積の減少からも, シリカシェルの細孔にチタニアが 入り达んだことによると考えられる。EDS 分析結果ほど のチタニアシェル厚の形成が TEM 観察では確認できな い理由は，ここにあると考えている。

Fig. 7 (a) に，各粒子を蒸留水中に分散（超音波処理 5 分）させた懸濁液の紫外線遮蔽能（100-透過率 [\%]）を 示す。シリカ中空粒子にチタニア被覆したことで紫外線 遮蔽能が向上し, 中でも $\mathrm{WT}_{2,2(50)}$ がもっともよい性能を 示した。Fig. 7 (b) に $\mathrm{WT}_{2.2(50)}$ の白色度計算のために測定 した拡散反射率を示す。アルミニウム（Al）を基板とし， 基板上に各粒子を塗布したものを測定サンプルとし, バッ クグラウンド補正には硫酸バリウムを用いた。実線で示 した $\mathrm{WT}_{2.2(50)}$ の拡散反射率は, 室温で合成した $\mathrm{WT}_{2.2}$ より も高く，市販チタニアに近づいていることがわかる。拡 散反射率測定結果をもとに，カラー測定ソフトウェアを
用いて白色度を算出すると, $\mathrm{WT}_{2.250)}$ で $90.89 \%, \mathrm{WT}_{2.2}$ は $88.18 \%$, 市販チタニアは 89.32\%であった。チタニア複合 化により白色度の高い粒子の作製が可能となった。

\section{4. 結 言}

炭酸カルシウムナノ粒子の凝集体をテンプレートとし, 多孔質構造を持つ中空粒子を合成, チタニアを複合化す る条件（蒸留水添加量および反応温度）を決定した。 $\left[\mathrm{H}_{2} \mathrm{O}\right] /[\mathrm{Ti}]$ 比を 2.2 , 反応温度を $50^{\circ} \mathrm{C}$ とすることで, 安定 化した TBOT-酢酸錯体の反応を促進し, シリカシェルと の複合化が可能となった。得られた複合中空粒子の白色 度は 90.89\%となり, 市販チタニア $89.32 \%$ を越える粒子 の設計が可能となった。

[謝辞] 本論文の一部はブラザー工業株式会社との共同研 究の成果である。炭酸カルシウムテンプレートの合成に は, 株式会社 NCAP の協力を得た。また, 本論文で使用 した市販チタニアは石原産業株式会社より提供いただい た。ここに記して謝意を表する。

\section{References}

[1] M. Fuji, C. Takai, H. Watanabe, K. Fujimoto, Improved transparent thermal insulation using nano-spaces, Adv Powder Technol. 26 (2015) 857-860.

[2] W. Suthabanditpong, C. Takai, M. Fuji, R. Buntem, T. Shirai, Improved optical properties of silica/UV-cured polymer composite films with hierarchical structure of hollow silica nanoparticles for light diffuser film applications, Phys. Chem. Chem. Phys. 18 (2016) 16293-16301.
[3] T. Ohno, T. Matsuda, N. Wakiya, H. Suzuki, Preparation of the $\mathrm{TiO}_{2}-\mathrm{SiO}_{2}$ nano-hybrid particles by nano-coating of $\mathrm{TiO}_{2}$ layer on monodispersed $\mathrm{SiO}_{2}$ nano-particles, Trans. Mater. Res. Soc. Japan 32 (2007) 155-158.

[4] P. K. Sharma, A. Ramanan, The role of N,N-dimethylaniline in the formation of titania gel monolith by sol-gel method, J. Mater. Sci. 31 (1996) 773-777.

[5] S. Doeuff, M. Henry, C. Sanchez, J. Livage, Hydrolysis of 
titanium alkoxides: Modification of the molecular precursor by acetic acid, J. Non-Cryst. Solids 89 (1987) 206-216.

[6] M. Fuji, Nano-hollow particle supported the official ball of volleyball game in Beijing Olympics, Funtai Gijutsu, 1 (2009) 23-31.

[7] M. Fuji, C. Takai, Y. Tarutani, T. Takei, M. Takahashi, Surface properties of nanosize hollow silica particles on the molecular level, Adv. Powder Technol. 18 (2007) 81-91.
[8] T. Yasue, A. Mamiya, Y. Takahashi, R. Tsukisaka, Y. Arai, Synthesis and characteristics of amorphous calcium carbonate, J. Chem. Soc. Japan, Chem. Ind. Chem. 7 (1984) 1107-1113.

[9] S. Baskaran, L. Song, J. Liu, Y. L. Chen, G. L. Graff, Titanium oxide thin films on organic interfaces through biomimetic processing, J. Am. Ceram. Soc. 81 (1998) 401408. 